\title{
Bazı Yeşil Mercimek Genotiplerinde Dane Verimi ve Verim Komponentleri Arasındaki İlişkilerin Belirlenmesi
}

\author{
*Ömer SÖZEN ${ }^{1}$ \\ Ufuk KARADAVUT ${ }^{2}$ \\ ${ }^{1}$ Ahi Evran Üniversitesi, Ziraat Fakültesi, Tarla Bitkileri Bölümü, Kırşehir \\ ${ }^{2}$ Ahi Evran Üniversitesi, Ziraat Fakültesi, Zootekni Bölümü, Kırşehir \\ *Sorumlu yazar e-posta (Correspondence author e-mail): eekim_55@hotmail.com \\ Geliş Tarihi (Received): 09.05.2017 \\ Kabul Tarihi (Accepted): 05.06.2017
}

\section{Öz}

Kırşehir ili ekolojik koşullarında yetiştiriciliği yapılan mercimek genotiplerinde verim ve verime etki eden unsurların belirlenmesi ile bu unsurlar arasındaki ilişkilerin ortaya koyulmasını amaçlayan bu araştırma 2013 ve 2014 yıllarında iki yıl süre ile yürütülmüştür. Araştırmada 3'ü yeşil mercimek çeşidi (Sultan, Ankara Yeşili ve Meyveci 2001) olmak üzere 6 adet yeşil mercimek genotipi kullanılmıştır. Araştırma tesadüf blokları deneme deseninde 4 tekrarlamalı olarak yürütülmüş olup ekimler 2013 yılında 28 Mart, 2014 yılında ise 24 Mart tarihinde gerçekleştirilmiştir. Araştırmada kullanılan yeşil mercimek genotiplerinin iki yıllık ortalamalarına göre bitki boyları 18-21.3 cm, bitkide bakla sayıları 14.3-25.7 adet, bitkide tane sayıları 10.7-18.5 adet, bin tane ağılıklarının ise 26.8-40.1 g arasında değişim gösterdiği belirlenmiştir. Ayrıca korelasyon analizi sonucunda biyolojik verim ile bitkide bakla sayısı, ilk bakla yüksekliği ile biyolojik verim, bitkide tane sayısı ile verim arasında çok önemli ilişkilerin olduğu belirlenmiştir. Sonuç olarak yeşil mercimek ıslah çalışmalarında bitkide bakla sayısı, bitki dane verimi ve ilk bakla yüksekliklerinin seleksiyon kriteri olarak dikkate alınmasının gerekliliği tespit edilmiştir.

Anahtar Kelimeler: Yeşil mercimek, tane verimi, verim komponentleri, korelasyon

\section{Determination of Relationship Between Yield and Yield Components in Some Green Lentil Genotypes}

\begin{abstract}
This research was carried out between 2013 and 2014 for two years, aiming to determine the factors affecting yield and yield components in the lentil genotypes cultivated in the Kirsehir ecological conditions and to reveal the relationship between these plant characters. In the study, 6 green lentil genotypes were used The research was conducted in completely randomized block design with three replications. Sowings were carried out on March 28 for 2013 and on March 24 for 2014. According to the results averaged two consecutive years plant height ranged from 18 to $21.3 \mathrm{~cm}$, number of pods per plant ranged from 14.3 to 25.7, number of seeds per plant ranged from 10.7 to $18.5,1000$ seed weight ranged from 26.8 to $40.1 \mathrm{~g}$. Positively correlations detected between the biological yield and the number of pods per plant, the first pod height and between the number of seeds per plant and grain yield. As a result, it has been determined that the number of pods per plant, grain yield and the first pod height in the green lentil breeding studies should be considered as selection properties.
\end{abstract}

Keywords: Green lentil, grain yield, yield components, correlation

\section{Giriş}

$\mathrm{D}$ ünya genelinde yaşanmaya başlanan gıda temin sorunu artarak devam etmektedir. Bu ihtiyaçların içinde en önemli olanı ise protein teminidir. Hayvansal kaynaklı proteinlerin pahalı olmasından dolayı gelişmekte olan ve az gelişmiş ülkelerde daha ucuz olmasından dolayı bitkisel kökenli proteinler oldukça önemlidir. Bitkisel protein kaynağı olarak en önemli bitki grubu, yüksek protein içerikleri nedeniyle yemeklik tane baklagillerdir.

Mercimek, yemeklik tane baklagiller arasında 4.3 milyon ha ekim alanı ve 4.9 milyon 
ton üretimi ile dünyada 5. sırada yer almasına rağmen ülkemizde 17 bin ha yeşil mercimek ve 230 bin ha kırmızı mercimek olmak üzere 247 bin ha ekim alanı ve 417 bin ton üretimi ile nohuttan sonra ikinci sırada gelmektedir. Dünya verim ortalaması mercimek için dekara 115 $\mathrm{kg}$ iken, ülkemizde ise özellikle son yılardaki başarılı ıslah çalışmaları sonucunda 148 kg'lık bir değere ulaşmıştır (Anonymous 2016).

Mercimek bitkisi hem protein miktarı (\%2331) hem de vitamin ( $A, B, C$ ve $D)$ ve mineral maddeler ( $\mathrm{Fe}, \mathrm{Mg}$, $\mathrm{Ca}, \mathrm{P}, \mathrm{K}$ ) bakımından oldukça zengindir (Şehirali 1988). Mercimek bitkisinde yüksek oranda leucine, isoleucine, lycine, phenylalaline ve valin gibi önemli aminoasitler bulunmaktadır (Saint-Clair 1972). $\mathrm{Bu}$ özelliğinden dolayı mercimeğin içermiş olduğu proteinler oldukça kalitelidir. Ayrıca proteinlerin hazmolunabilirlik özelliği de (\%92) oldukça yüksektir (Bressani 1973). Bu özelliğinden dolayı mercimek bitkisi beslenme programlarında olması gereken bir besin kaynağıdır (Arora 1981).

Mercimek bitkisi sahip olduğu özelliklerinden dolayı üzerinde çok çalışılan bitkiler arasındadır. Özellikle kurak iklim koşullarında çok iyi uyum sağlaması ve başarılı bir şekilde üretilme imkanına sahip olması bu ürünü vazgeçilmez kılmaktadır (Lazaro ve ark. 2001). Bildirici ve Çiftçi (2001)'nin Van ekolojik koşullarında 9 mercimek genotipinde (Kışlık Kırmızı-51, Yerli Kırmızı ve Fırat-87, FLIP8635L, ILL-468, FLIP86-29L, FLIP90-26L, FLIP89-30L ve ILL-1930) bitki boyunun 22.2$25.8 \mathrm{~cm}$, ilk bakla yüksekliğinin $12.5-15.1 \mathrm{~cm}$, bitkide ana dal sayısının 2.2-2.99 adet, baklada tane sayısının 1.19-1.58 adet, 1000 tane ağırlıklarının 36.6-45.1 g arasında değiştiğini belirtmişlerdir. Ayrıca tane verimi ile bitki boyu $\left(0.338^{* *}\right)$, verim ile bitkide bakla sayısı $\left(0.419^{* *}\right)$, verim ile bitkide tane sayısı $\left(0.239^{*}\right)$ ve bitkide tane verimi $\left(0.301^{*}\right)$ arasında olumlu ve önemli ilişkiler tespit etmişlerdir. Buna karşın verim ile baklada tane sayısı arasında ise önemli ancak olumsuz $\left(-0.322^{* *}\right)$ ilişkiler olduğunu belirlemişlerdir.

Akdağ ve Düzdemir (2002), Tokat koşullarında yaptıkları çalışmada mercimekte tane verimlerinin 93.78-172.56 kg/da arasında değiştiğini belirtmişlerdir. Biçer ve Şakar (2003), Diyarbakır koşullarında mercimekte çiçeklenme zamanının 93.13-110.0 gün, olgunlaşma zamanının ise 98.13-135 gün, bitkide bakla sayısını 15.5-23.56 adet, 1000 tane ağırlığı 40.88-31.63g ve verimin ise $182.91-232.56 \mathrm{~kg} / \mathrm{da}$ arasında değişim gösterdiğini ifade etmişlerdir. Aynı araştırıcılar en yüksek ilişkinin bitkide bakla sayısı ile bitkide tane sayısı $\left(0.738^{* *}\right)$, biyolojik verim ile tane verimi $\left(0.593^{* *}\right)$, bitkide tane sayısı ile baklada tane sayısı $\left(0.497^{\star *}\right)$, biyolojik verim ile bitki boyu $\left(0.387^{* *}\right)$ arasında olduğunu tespit etmişlerdir. Toklu ve ark. (2009) kırmızı mercimek yerel genotipleri arasında dane verimi ve verim komponentleri yönünden önemli farklılıklar saptadıklarını bildirerek, bitkide bakla sayısı, bitkide tohum sayısı ve 1000 tane ağırlığı özelliklerinin dane verimi üzerinde etkili karakterler olduğunu bildirmişlerdir.

Çölkesen ve ark. (2014) 12 farklı kırmızı mercimek çeşidiyle yaptıkları çalışmada; en yüksek verimin FLIP 2007-106L (368 kg/da), FLIP 2005-58L (310 kg/da) ve FLIP 2005-20L (298 kg/da) genotiplerinden elde edildiğini belirtmişlerdir. Ayrıca en erkenci genotiplerin ise FLIP 2005-20L (145 gün), FLIP 200558L (151 gün) ve FLIP2007-106L (152 gün) olduğunu tespit etmişlerdir. Karadavut ve Palta (2010), 10 farklı mercimek genotipinin üç yıl ve dört farklı çevrede kimyasal performanslarının test edildiği çalışmada Fırat 87 genotipinin bütün çevrelerde benzer tepkiyi gösterdiği ve en kararlı genotip olduğu görülmüştür.

$\mathrm{Bu}$ çalışmanın amacı, Kırşehir ekolojik şartlarında bazı yeşil mercimek genotiplerinin verim ve verim komponentleri ile karakterler arasındaki ilişkilerin belirlenmesi olarak özetlenebilir.

\section{Materyal ve Metot}

Bu çalışma, 2013 ve 2014 yıllarında İç Anadolu Bölgesi sınırları içinde yer alan Kırşehir ekolojik koşullarında Ahi Evran Üniversitesinin Bağbaşı yerleşkesinde yer alan Araştırma ve Uygulama Arazisi'nde yürütülmüştür. Araştırma alanının topraklarının kumlu-tınlı yapıda, toprak reaksiyonunun ( $\mathrm{pH}=7.86)$ nötre yakın, organik madde (\%1.85), ile fosfor (2.16 ppm) içeriğinin düşük, kireç oranının (\%15.34) orta derecede ve potasyumca yeterli $(1.44 \mathrm{Me} / 100 \mathrm{~g})$ olduğu belirlenmiştir. Çalışmanın yürütüldüğü 2013 ve 2014 yılları vejetasyon mevsimi ile uzun yıllar ortalama iklim verileri (ortalama yağış, ortalama sıcaklık ve nispi nem) Çizelge 1'de verilmiştir.

Çizelge 1 incelendiğinde 2013 yılının 2014 yılından daha sıcak ve kurak geçtiği görülmektedir. Uzun yıllar ve deneme yılları karşılaştırıldığında en yağışlı yılın 2014 yılı olduğu, aylık ortalama sıcaklık değerleri bakımından her iki yıllık değerler ile uzun yıllar değerleri arasında benzerlik olduğu 
Sözen ve Karadavut "Bazı Yeşil Mercimek Genotiplerinde Verim ve Verimle Illgili Özellikler Arasındaki İlişkilerin Belirlenmesi”"

Çizelge 1. Kırşehir Ili'ne ait 2013 ve 2014 yılları ile uzun yıllar iklim verileri* Table 1. Climate data for the Kırsehir*

\begin{tabular}{|c|c|c|c|c|c|c|c|c|c|}
\hline \multirow{2}{*}{ Aylar } & \multicolumn{3}{|c|}{ Ortalama Sıcaklık $\left({ }^{\circ} \mathrm{C}\right)$} & \multicolumn{3}{|c|}{ Toplam Yağış (mm) } & \multicolumn{3}{|c|}{ Ortalama Nispi Nem (\%) } \\
\hline & 2013 & 2014 & Uzun Yıllar & 2013 & 2014 & Uzun Yıllar & 2013 & 2014 & Uzun Yıllaı \\
\hline Mart & 7.2 & 7.4 & 6.3 & 14.2 & 52.2 & 9.3 & 63 & 64.3 & 67.5 \\
\hline Nisan & 12 & 13.2 & 11.4 & 45.1 & 20.2 & 7.7 & 62.8 & 54.9 & 59.7 \\
\hline Mayıs & 19.3 & 16.9 & 16.2 & 15.1 & 46.6 & 10.7 & 44.7 & 59.5 & 56.2 \\
\hline Haziran & 21.4 & 20.8 & 20.6 & 1 & 36 & 13.9 & 42 & 51.6 & 50.9 \\
\hline Temmuz & 24.1 & 27.6 & 24.8 & 6.6 & 13 & 2.9 & 37.1 & 33.6 & 38.4 \\
\hline Ortalama & 16.8 & 17.2 & 15.9 & & & & 52.5 & 52.8 & 54.5 \\
\hline Toplam & & & & 82 & 168 & 44.5 & & & \\
\hline
\end{tabular}

*Kırşehir İI Meteoroloji Müdürlüğü *Kırşehir Provincial Meteorology Directorate görülmektedir.

Araştırmada 3 standart çeşit (Sultan, Ankara Yeşili ve Meyveci 2001) ile 3 yerli popülasyon (Hacıbektaş 1, Altınekin/Konya, Hacıbektaş 2) kullanılmıştır.

Araştırma, tesadüf blokları deneme desenine göre 4 tekrarlamalı olarak kurulmuştur. Ekimler $20 \mathrm{~cm}$ sıra arası mesafede çiziler markör ile açılarak tohumlar el ile ekilmiştir. Parsel büyüklükleri; $0.8 \mathrm{~m}$ x $5 \mathrm{m=} 4 \mathrm{~m}^{2}$ olacak şeklinde düzenlenmiştir. Gübreleme dekara $2.5 \mathrm{~kg}$ saf azot ve $5 \mathrm{~kg}$ saf fosfor üzerinden DAP gübresi olarak verilmiştir. Ot mücadelesi çiçeklenme öncesine bir ve çiçeklenme sonrasında bir kez olmak üzere toplam iki kez elle yapılmıştır.

$\% 50$ çiçeklenme ve bakla bağlama gün süreleri tüm parsel üzerinden yapılmıştır. Bitki boyu, ilk bakla yüksekliği, biyolojik verim, bitkide bakla sayısı, bitki başına verim, bitkide tane sayısı, bin tane ağırlığı $(\mathrm{g})$ ölçümleri için her parselin ortasındaki 2 sıradan rastgele 10 bitki seçilmiş ve bunların ortalama değerleri hesaplanmıştır. Tohum verimi parselin ortasındaki 2 sıra ve 4 metrelik kısımdan 0.4 x 4= 1.6 metrekarelik alan üzerinden yapılmıştır.

Çalışmadan elde edilen veriler, yıllar birleştirilerek varyans analizine tabi tutulmuş olup karakterlere ait eldeki uygulamalar

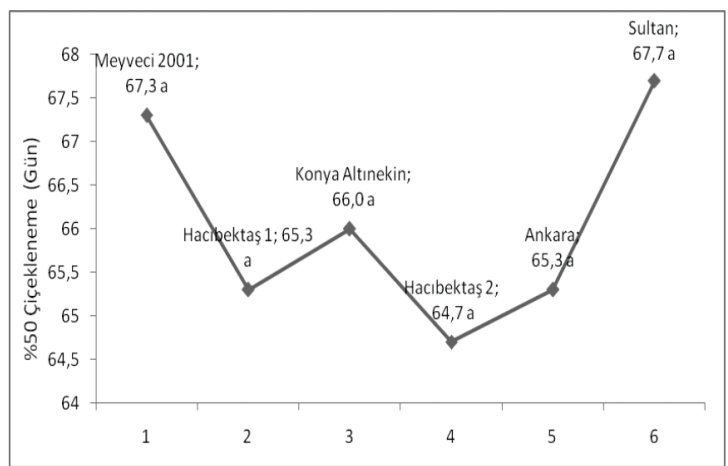

Şekil 1. \%50 çiçeklenme ve bakla bağlama gün sayıları Figure 1.50\% flowering and $50 \%$ pod binding period arasındaki farkılığın istatistiksel kontrolünde F testi uygulanmıştır. İstatistiki düzeyde önemli bulunan karakterler için ortalamalar arasındaki farkların gruplandırması EGF testine göre $(P>0.05)$, karakterler arası ilişkiler için korelasyon analizi yapılmıştır (Düzgüneş ve ark. 1987). İstatistiki analizler için MINITAB 14 $\mathrm{V}$ istatistik paket programı kullanılmıştır.

\section{Bulgular ve Tartışma}

İncelenen özelliklerden \%50 çiçeklenme ve $\% 50$ bakla bağlama gün sürelerine ilişkin sonuçlar Şekil 1'de gösterilmektedir. Her iki özellik içinde genotipler arasında istatistiksel olarak önemli bir farkın olmadığı gözlenmektedir. Kurak iklim şartlarının hâkim olduğu ilde özellikle sıcakların aniden ve yüksek oranda olması çiçeklenmeyi ve bakla bağlamayı teşvik etmektedir. Bu da genotipler arasındaki farklılığın kapanmasına neden olmuş olabilir.

Şehirali(1988), çiçeklenmenin havasıcaklığı ve havanın nemi ile doğrudan ilişkili olduğunu ve bu faktörlerdeki artışın çiçeklenmeyi teşvik ettiğini azalmanın ise açılmamayı teşvik ettiğini belirtmiştir. Chakraborty ve Haque (2000) ile Aydoğan ve ark. (2003) çiçeklenme gün sayısında varyansın çok düşük olduğunu ve değişimin az olmasının normal karşılanması gerektiğini bildirmişlerdir. Erksine ve Sarker (1997) Hindistan ve Bangladeş'te verim kaybının \%62'lik kısmının erken çiçeklenme

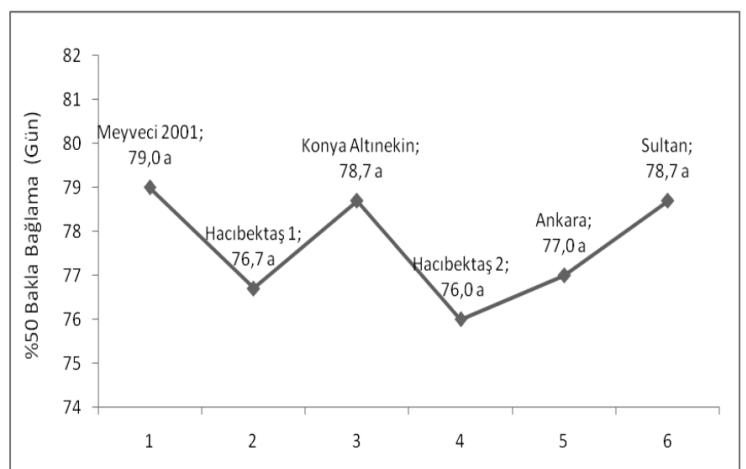




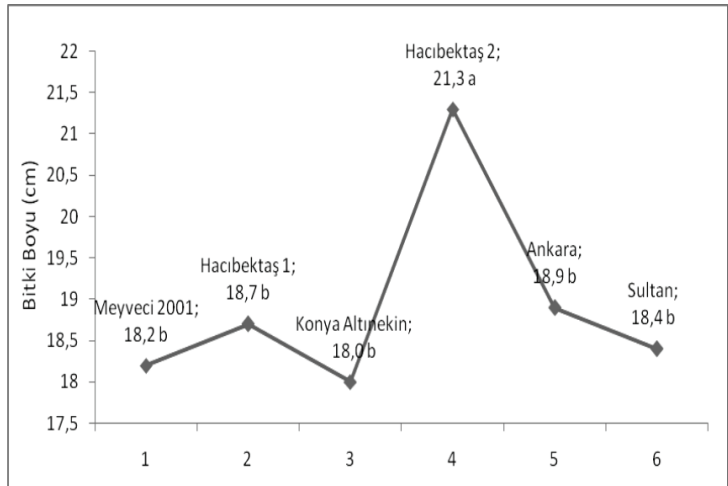

Şekil 2. Bitki boyu ve ilk bakla yüksekliği

Figure 2. Plant height and the first pod height

ve buna bağlı olarak erken olgunlaşmadan kaynaklandığını belirtmiş̧lerdir.

Bitki boyu ile ilk bakla yüksekliği değerlerine ait sonuçlar Şekil 2'de gösterilmektedir. Bitki boyu bakımından çok yüksek bir varyasyonun olmadığı sadece Hacıbektaş 2 genotipinin diğer genotiplerden ayrıldığı görülmektedir. Diğer genotipler ise birbirlerine yakın değerler göstermişlerdir. İlk bakla yüksekliği bakımından ise saptanan varyasyon bitki boyuna kıyasla biraz daha yüksek olmuştur. Meyveci 2001 ve Ankara Yeşili genotipleri ilk bakla yüksekliği bakımından ön sıralarda yer alırken, bunları Sultan genotipi izlemiştir. Ancak Hacıbektaş 2 genotipinin bitki boyu değeri yüksek olmasına rağmen ilk bakla yüksekliği çok düşük değer almıştır (Şekil 2). Bu sonuç Hacıbektaş 2 genotipinin makineli hasata uygun olmadığının bir göstergesi olarak değerlendirilmiştir. Yemeklik tane baklagillerde ekolojik koşulların bitki boyu ve ilk bakla bağlama zamanını doğrudan etkilediği bildirilmiştir (Summerfield 1981). Biçer ve Şakar (2003a) mercimek bitkisinin kışlık ekim yapılması durumunda bitki boyu ve ilk bakla yüksekliğinin artacağını

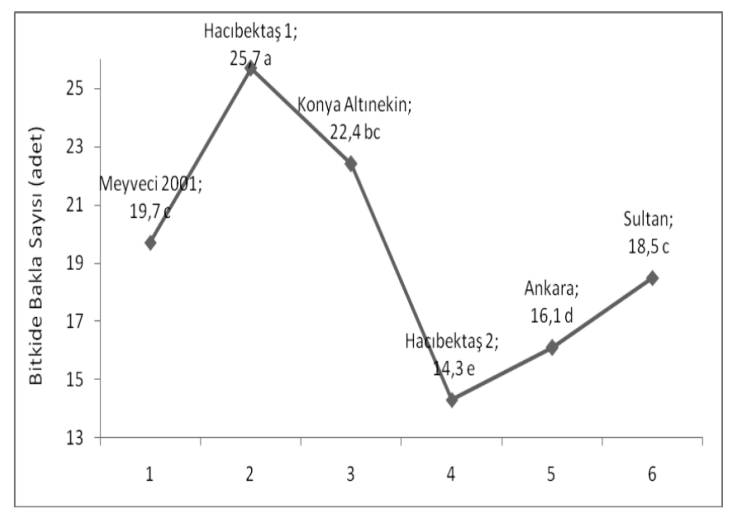

Şekil 3. Bitkide bakla sayısı ve bitki dane verimi

Figure 3. The number of pods per plant and the grain yield per plant

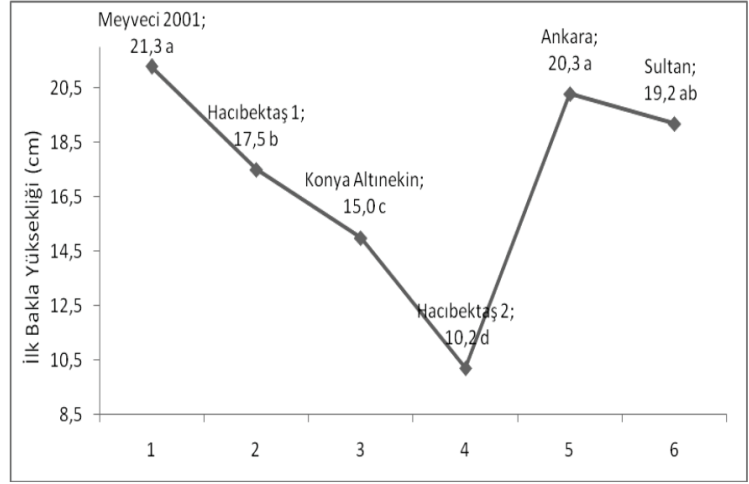

belirtmişlerdir. Çölkesen ve ark. (2014) Kahramanmaraş koşullarında belirtilen özellikler bakımından büyük varyasyonun olduğunu açıklamışlardır. Elde ettiğimiz sonuçlar araştırmacıların bulguları ile benzerlik göstermektedir.

Bitkide bakla sayısı ve bitkide tane verimine ilişsin sonuçların verildiği Şekil 3'de her iki özellikte de büyük varyasyonun olduğu görülmektedir. Ancak değişim konusunda iki özellik içinde genotiplerin verdikleri tepkiler aynı olmuştur. Bitkide bakla sayısı ve bitki tane verimi bakımından Hacıbektaş 1 genotipi en yüksek değeri alırken, Hacıbektaş 2 genotipi ise her iki özellik içinde en düşük değere sahip olmuştur. Ancak Ankara Yeşili genotipinin diğerlerinden ayrılarak aynı kararlıı̆̆ı göstermediği gözlenmiştir.

Akdağ ve Düzdemir (2002), bu özelliklerin özellikle yazlık ekimde daha düşük değerler aldığını ve kışlık ekimde daha iyi sonuçların alınabileceğini belirtmişlerdir. Araştırmacıların saptadığı bulgular ile bizim elde ettiğimiz sonuçlar benzerlik göstermektedir. Çokkızgın ve ark. (2005) Kahramanmaraş koşullarında

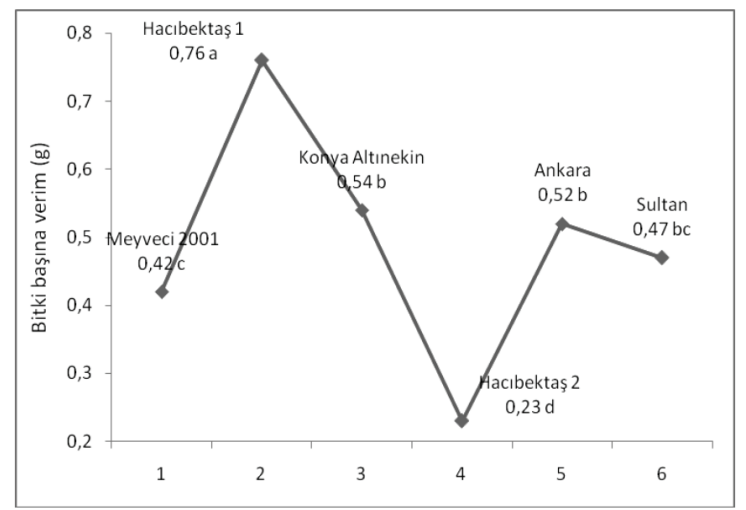


bu özellikler bakımından genotipler arasında farklılığın olmadığını ancak yıl etkisinin yüksek olduğunu belirtmişlerdir. Araştırmacıların elde ettiği bulgular ile bizim bulgularımız farklılık göstermektedir. Bunun sebebinin Kahramanmaraş ekolojik koşullarının Kırşehir ili ile çok benzer özelliğe sahip olmadıklarından kaynaklandığı tahmin edilmiştir.

Bitkide tane sayısı ile bin tane ağırlığı özelliklerine ait değerlerin verildiği Şekil 4 incelendiğinde varyasyonun yüksek olduğu görülmektedir. Genotiplerin bitkide tane sayısında gösterdikleri tepkileri bin tane ağırlığı bakımından da göstermeleri beklenirken böyle olmamış ve çok farklı sonuçlar elde edilmiştir. Bitkide tane sayısı bakımından Hacıbektaş 1 genotipi en yüksek değere sahip olurken, bin tane ağırlığında Meyveci 2001 ve Konya Altınekin genotipleri ilk sırada yer almışlardır. Benzer şekilde bitkide tane sayısı bakımından en düşük değer Ankara Yeşili genotipinde gözlenirken, bin tane ağırlığı bakımından ise en düşük değer Sultan ve Hacıbektaş 2 genotiplerinde gözlenmiştir.

Bitkide tane sayısı ile bin tane ağırlığı değerleri birbirlerini desteklememişlerdir. $\mathrm{Bu}$ durum dane dolum döneminde oluşan yüksek sıcaklıklar ve bu sıcaklıkların etkisi ile bitkilerin daneleri yeterince dolduramaması ile açıklanabilir. Yımaz ve ark. (1996), yaptıkları çalışmada özellikle generatif dönemda karşılaşılan yüksek sıcaklıkların tane dolumunu olumsuz yönde etkilediğini belirtmşlerdir. Bucak ve ark. (2003), yaptıkları çalışmada benzer sonuçlar elde etmişlerdir. Biçer (2014), nohut ve mercimek bitkilerinde gübrelemeye karşı en olumlu tepkileri bitkide tane sayısı ile baklada tane sayısının verdiğini belirtmiştir. Bu çevresel değişimin bitki büyümesine nasıl etki yapacağının belirlenmesi

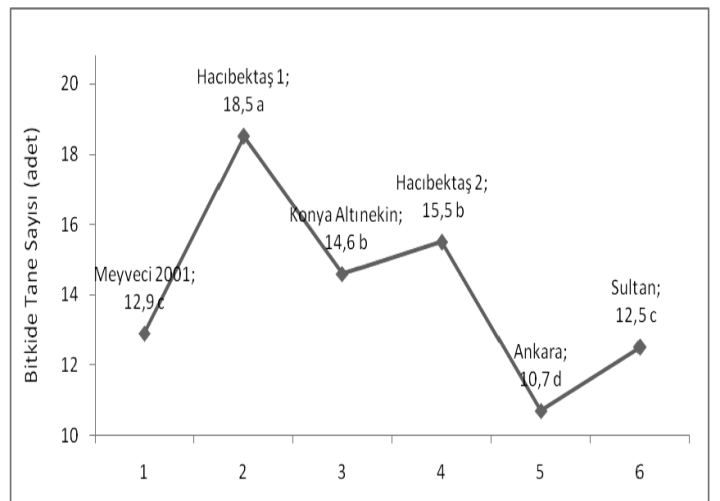

Şekil 4. Bitkide tane sayısı ve bin tane ağırlığı

Figure 4. The number of seeds per plant and 1000-seed weight açısından önem taşımaktadır. Elde ettiğimiz sonuçlar araltırmacıların bulguları ile benzelik göstermektedir.

Biyolojik verim ve verim ile ilgili elde edilen sonuçlara göre hem biyolojik verim ve hemde dane verimi bakımından genotiplerin benzer tepkiler gösterdikleri görülmektedir (Şekil 5). Hacıbektaş 1 genotipi her iki özellik içinde en yüksek değeri alırken, en düşük değer ise Hacıbektaş 2 genotipinde görülmüştür. Diğer genotiplerde de sıralama benzer olmuştur. Çokkızıgın (2007), yaptığı çalışmada dane veriminin 117 ile 323 kg/da arasında değişiklik gösterdiğini ve varyasyonun çok geniş olduğunu belirtmiştir. Biyolojik verim bitkinin toprak üzerindeki bütün aksamıdır. Dane verimi ve biyolojik verimin yağışın etksinde olduğu bilinmektedir (Günel ve ark. 1994). Yağış olması durumunda bu özelliklerin değeri artmakta yağışın azalması ile değerler düşmektedir.

Karadavut(2009), yaptığıçalışmadabiyolojik verim ve verim bakmından genotiplerdeki varysayonda ilkbahar sıcaklıklarının beklenenden önce ve yüksek oranda bastırması olduğunu belirtmiştir. Yaptığımız çalışmada da her iki yılda da sıcaklıklar normal şartlardan daha erken gelmiştir. Bu da bitkileri büyümeye ve erken olgunlaşmaya zorlamıştır. Böylece biyoojik verim ve verimde olması gerekenin çok altında sonuçlar elde edilmiştir. Benzer sonuçları Gharti ve ark. (2008)'de belirtmiştir.

Korelasyon analizi sonuçları Çizelge 2'de gösterilmektedir. Biyolojik verim ile dane verimi arasındaki ilişki $p<0.05$ düzeyinde, bitkide tane sayısı ile dane verimi arasındaki ilişki $p<0.01$ düzeyinde önemli bulunmuştur. Karadavut (2009), yaptığı çalışmada verim ile biyolojik verim ve hasat indeksi ile verim arasında yüksek oranda pozitif yönlü ilişki olduğunu belirtmiştir. Kakde ve ark. (2005), bitkide tohum verimi ile

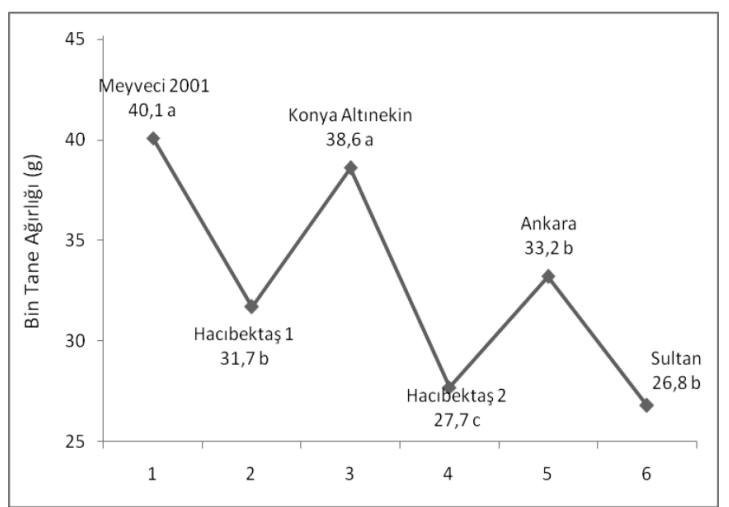



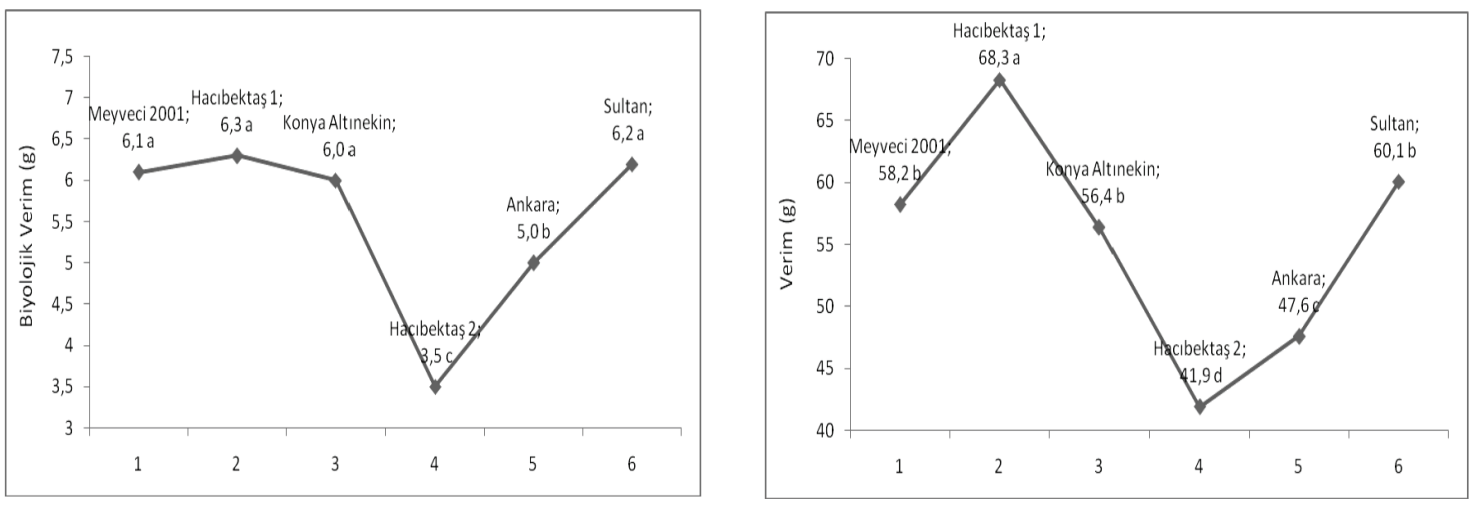

Şekil 5. Biyolojik verim ve dane verimi

Figure 5. Biological yield and grain yield

Çizelge 2. Dane verimi ve verime etkili karakterler arasındaki ilişkiler

Table 2. The relationship of grain yield and yield components

\begin{tabular}{llc}
\hline \multicolumn{2}{c}{ Karakterler Arası İlişkiler } & Korelasyon Katsayısı (r) \\
\hline \%50 çiçeklenme gün sayısı & \%50 Bakla bağlama gün sayısı & $0,468^{*}$ \\
\%50 bakla bağlama gün sayısı & Biyolojik verim & $0,525^{*}$ \\
Bitki boyu & İlk bakla yüksekliği & $-0,475^{*}$ \\
İlk bakla yüksekliği & Biyolojik verim & $0,607^{* *}$ \\
İlk bakla yüksekliği & Bitki dane verimi & $0,505^{*}$ \\
Biyolojik verim & Bitkide bakla sayısı & $0,745^{* *}$ \\
Biyolojik verim & Bitkide tane sayısı & $0,725^{* *}$ \\
Biyolojik verim & Dane verimi & $0,457^{*}$ \\
Bitkide bakla sayısı & Bitki dane verimi & $0,860^{* *}$ \\
Bitkide tane sayısı & Bitkide bakla sayısı & $0,544^{*}$ \\
Bitkide tane sayısı & Dane verimi & $0,453^{* *}$ \\
\hline
\end{tabular}

hasat indeksi arasında pozitif ve önemli ilişki olduğunu ancak bitkide bakla sayısı ile hasat indeksi arasında negatif ve önemli ilişkiler olduğunu belirtmişlerdir. Buna göre bitkide tane sayısının verimi etkileme bakımından en önemli karakter olduğu söylenebilir.

Bitki boyunun artması genel olarak ilk bakla yüksekliği değerini de artırmaktadır. Ancak yapılan çalışmada tam tersi bir sonuç elde edilmiştir. Biyolojik verim ile bitkide tane sayısı ve bitkide tane verimi arasında çok önemli ilişkilerin çıkması da biyolojik verimi bakla gelişiminin doğrudan ve önemli ölçüde etkilediğini göstermektedir.

\section{Sonuç}

Yapılan çalışmada 6 farklı yeşil mercimek genotipi kullanılmıştır. Bu genotiplerin dane verimi ve verime etki eden karakterleri belirlenmiştir. Hacıbektaş 2 genotipinin genel olarak diğer genotiplerden daha başarılı olduğu tespit edilmiştir. Bu genotipi Meyveci 2001, Konya Altınekin ve Sultan genotipleri izlemiştir. En düşük değer ise Hacıbektaş 1 genotipinde görülmüştür.

Yapılan çalışmada sonuç olarak, bitkide bakla sayısı ve bitki dane verimi üzerinde özellikle durulması gerektiği ortaya çıkmaktadır. Ekolojik faktörlerin bitki yetiştiriciliğinde temel belirleyiciler arasında olduğu bu çalışma sonucunda da açıkça ortaya konulmuştur. Özellikle kurak iklim koşulları altında yapılan çalışmalarda kurağa toleranslı genotiplerin üzerinde durulması yetiştiriciliğin geleceği açısından faydalı olacaktır. İklimin belirleyici olması aynı zamanda yeni genotipleri geliştirirken bu faktörün ön plana alınması şartını da getirmektedir. Yapılan bu çalışmada Hacıbektaş 1 genotipi bölgenin yerel genotipi olması nedeniyle daha başarılı bir performans sergilemiştir.

\section{Kaynaklar}

Akdağ C. ve Düzdemir O., 2002. Tokat ekolojik şartlarında kışlık ve yazlık ekime uygun mercimek (Lens culinaris Medic.) çeşitlerinin belirlenmesi. Gazi Osman Paşa Üniversitesi Ziraat Fakültesi Dergisi, 19(1):69-73

Anonymous., 2016. http://fao.org/faostat/data/QC (Erişim tarihi: 10.04.2017)

Arora S.K., 1981. Chemistry and Biochemistry of Legumes. Edward Arnold, London 
AydoğanA., Aydın N., KaragözA., Karagül V., Horan A. ve Gürbüz A., 2003. İç Anadolu ve kuzey geçit bölgelerindeki yeşil mercimek (Lens culinaris Medic.) genetik kaynaklarının toplanması, karakterizasyonu ve ön değerlendirmesi. Türkiye 5. Tarla Bitkileri Kongresi, 13-17 Ekim, 160-165

Biçer T. ve Şakar D., 2003a. Diyarbakır koşullarında yeşil mercimek (Lens culinaris Medic.) hatlarının bazı morfolojik ve tarımsal karakterlerinin belirlenmesi. Türkiye 5. Tarla Bitkileri Kongresi, 13-17 Ekim, 508-510

Biçer T. ve Şakar D., 2003b. Farklı lokasyonlarda bazı mercimek (Lens culinaris Medic.) hat ve çeşitlerinde verim ve verim öğelerinin belirlenmesi. Türkiye 5. Tarla Bitkileri Kongresi, 13-17 Ekim, 504-507

Biçer B.T., 2014. Some agronomic studies in chickpea (Cicer arietinum L.) and lentil (Lens culinaris Medic). Türk Tarım ve Doğa Bilimleri Dergisi 1(1):42-51

Bildirici N. ve Çiftçi V., 2001. Van ekolojik koşullarında yüksek verimli kışlık mercimek (Lens culinaris Medic.) çeşitlerinin tane verimi ile verim öğeleri arasındaki ilişkilerin belirlenmesi üzerine bir araştırma. Çukurova Üniversitesi Ziraat Fakültesi Dergisi, 16(1):67-72

Bressani R., 1973. Legumes in human diets and how they might be improved. Ed: MILNER, M., Nutritional Improvement of Food Legume by Breeding. New-York, 389

Bucak B., Al V., Baysal İ. ve Polat T., 2003. Kırmızı mercimekte alternatif hat ve çeşitler. GAP III. Tarım Kongresi 02-03 Ekim, Şanlıurfa, 555558

Chakraborty M. and Haque M.F., 2000. Genetic variability and component analysis in lentil (Lens culinaris). Journal of Research, Birsa Agricultural University, 12(2):199-204

Cokkızgın A., Colkesen M., Kayhan K. and Aygan M., 2005. A research on yield and yield components in different winter lentil (Lens culinaris Medic.) cultivars under Kahramanmaras conditions. University of Akdeniz, Journal of Agricultural Faculty, 18(2):285-290

Çokkızgın A., 2007. Güney ve Güneydoğu Anadolu bölgelerinden toplanan bazı kırmızı mercimek (Lens culinaris Medic.) yerel genotiplerinin bitkisel ve tarımsal özelliklerinin belirlenmesi üzerine bir araştırma. Doktora tezi, Çukurova Üniversitesi Fen Bilimleri Enstitüsü, Adana

Çölkesen M., İdikut L., Zulkadir G., Çokkızgın A., Girgel Ü. and Boylu Ö.A., 2014. Determination of yield and yield components of various winter (Lens culinaris Medic.) lentil genotypes in Kahramanmaras conditions.
Turkish Journal of Agricultural and Natural Sciences, (1):1247-1253

Duzgunes O., Kesici T., Kavuncu O. and Gurbuz F., 1987. Research and trial methods. Journal of Agricultural Faculty of Ankara University, 381

Erskine W. and Sarker A., 1997. Lentil: the Bangladesh breakthrough. ICARDA Carvan No. 6

Gharti D.B., Jha P., Darai R., Ghale D., Joshi S. and Wagle B.P., 2008. Studies on management of stemphylium blight (Stemphylium sarciniforme) of lentil (Lens culinaris L.) at NGLRP, Rampur and RARS, Nepalgunj. In: Program and Abstract of a $27^{\text {th }}$ National Winter Crops Workshop "Ensuring Food Security Through Crop Diversification". Nepal Agricultural Research Council, 35-36

Günel E., Yılmaz N., Erman M. ve Kulaz H., 1994. Van ekolojik kosullarında mercimegin (Lens culinaris Medic.) çesit ve adaptasyonu üzerine arastırmalar. Tarla Bitkileri Kongresi, 25-29 Nisan, İzmir

Kakde S.S., Sharma R.N., Khilkre A.S. and Lambade B.M. 2005. Correlation and path analysis studies (Lens culinaris L.). Journal of Soils and Crops. 15(1):67-71

Karadavut U., 2009. Path analysis for yield and yield components in lentil (Lens culinaris Medic.). Turkish Journal of Field Crops, 14(2):97-104

Karadavut U. and Palta Ç., 2010. Chemical performance of multi environment trials in lentil (Lens culinaris Medic.). Journal of the Science of Food and Agriculture, 90:117-120

Lazaro A., Ruiz M., Rosa L. and Martin I., 2001. Relationships between agro/ morphological characters and climatic parameters in Spanish landraces of lentil (Lens culinaris Medic.). The Netherlands. Kluver Academic Publishers, 48(3):239-249

Saint-Clair P.M., 1972. Responses of Lens esculenta Moench to controlled environmental factor. $\mathrm{H}$. Weenmen-Zone N.V. Wageningen 84

Summerfield R.J., 1981. Adaptation to environments. Lentils (C. Webb and G. Hawtin ed.), 91110, Commonwealth Agricultural Bureaux, Farnham Royal, Slough SL2 3BN, England

Şehirali S., 1988. Yemeklik Tane Baklagiller. Ankara Üniversitesi Ziraat Fakültesi Yayınları:1089, Ders Kitabı: 314, Ankara, 435

Toklu F., Bicer B.T. and Karakoy T., 2009. Agromorphological characterization of the Turkish lentil landraces. African Journal of Biotechnology, 8(17):4121-4127

Yılmaz N., Erman M. ve Kulaz, H., 1996. Van ekolojik koşullarında mercimekte (Lens culinaris Medic.) uygun ekim zamanının belirlenmesi 